\title{
原著
}

\section{良性卵巣囊腫の診断にて腹腔鏡下手術を行い悪性腫瘍と判明した症例の検討 Malignant ovarian tumors which were diagnosed benign ovarian cysts before laparoscopic surgery}

\author{
日本医科大学産婦人科 \\ 黑瀬圭輔、阿部 崇、西 弥生、石川温子、石川 源 \\ 渡辺美千明、明楽重夫、竹下俊行
}

\begin{abstract}
緒言
腹腔鏡下手術の手技拧よび使用機械の開発・改 良はめざましい進歩をとげて打り、その適応は婦 人科良性疾患のほぼすべてが対象となっている。 良性卵巣囊腫に対する腹腔鏡下手術は手術侵襲が 少なく、入院期間の短縮、早期社会復帰などが可 能であり、開腹術より多くの利点があるといわれ ている。しかし卵巣腫場の良性・悪性を術前に完 全に鑑別することは不可能であり、また腹腔鏡下 手術の場合、ほとんどの症例において術中被膜破 綻が陽性となるため、悪性卵巣腫瘍の可能性につ いては十分に注意しなければならない。当科にお いては術前に超音波検查、MRI検查、腫瘍マーカ 一などを用いて卵巣腫瘍を評価し、悪性腫瘍が除 外できた場合は、ほとんどすべての症例に対して 腹腔鏡下手術を行なっている。今回、術前評価に て良性卵巣囊腫と診断して腹腔鏡下手術を行った が、術中あるいは術後病理診断にて悪性卵巣腫瘍 と診断された症例を経験したので報告する。
\end{abstract}

\section{症例}

\section{症例 1}

27歳 0 回経妊 0 回経産 性交涉経験なし

主訴：下腹部腫瘤感

家族歴・既往歴：特記すべきことなし

現病歴 : 半年ほど前より下腹部腫瘤感を自覚して いたが、それが増悪してきたので当科初診した。 多発子宮筋腫、左皮様囊胞腫の診断にてGnRHa療 法を 6 回施行後、手術目的にて入院となった（図 1)。吊り上げ式による体外法にて腹腔鏡補助下 子宮筋腫核出術㧍よび左卵巣囊腫切除術を施行し た。術前腫瘍マーカーはSCC : $1.6 \mathrm{ng} / \mathrm{ml}$ と軽度上

図 1 症例 1 MRI T2強調画像 a. 矢状断面 b. 横断面 直径 $4 \mathrm{~cm}$ 大の卵巣腫瘍がみられる。子宮には後壁を中心に多 発性の子宮筋腫が存在していた。
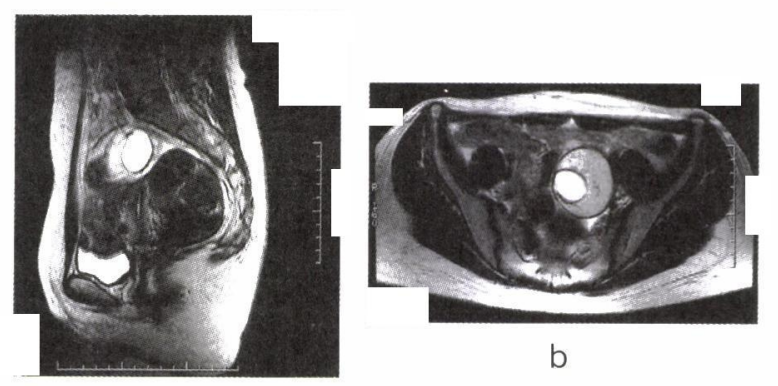

b

a

昇以外は、CA125：25.3 U/ml、CA19-9：19.4 $\mathrm{U} / \mathrm{ml} 、 \mathrm{CEA} ： 1.5 \mathrm{ng} / \mathrm{ml}$ な゙すべて正常範囲であ つた。

病理結果は「Immature teratoma, Grade1およ びLeiomyoma」であった（図 2 )。

再入院し開腹にて左付属器切除術および右卵巣 部分切除術を施行した。摘出標本には悪性所見を 認めなかった。術後約 2 年経過するが、再発兆候 を垫めず現在外来フォロー中である。

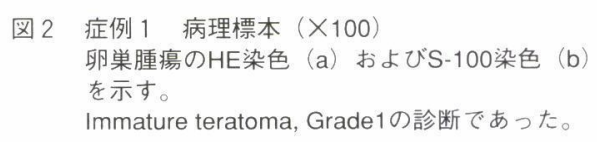

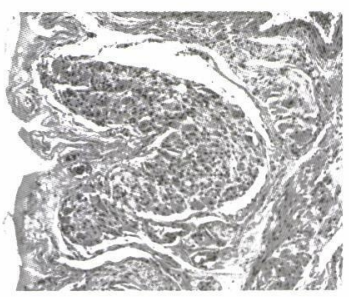

a

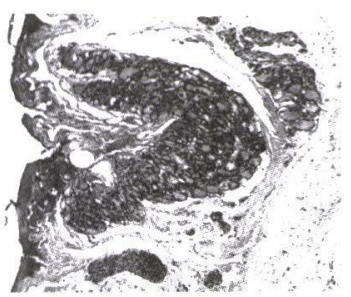

b 
症例 2

32 歳 0 回経妊 0 回経産

主訴：月経痛

家族歴：特記すべきことなし

既往歴：23歳左子宮内膜症性囊胞のため開腹にて 囊胞切除術を施行

現病歴：以前より子宮内膜症による月経痛強く、 GnRHa療法、低用量ピル、ダナゾール療法などを 施行。今回両側卵巣囊腫を認め手術目的にて入院 となった（四 3 ）。子宮内膜症による癒着が考え られたため、気腹式による体内法にて、腹腔鏡下 両側卵巣囊腫切除術を施行。肉眼上は両側子宮内 膜症性塞胞と左粘液性豪胞腫瘍が混在していた。 術前腫瘍マーカーはCA19-9のみ $164.0 \mathrm{U} / \mathrm{ml}$ と上昇 しており、その他CA125：21.0 U/ml、CEA : 1.0 $\mathrm{ng} / \mathrm{ml}$ SCC : $0.8 \mathrm{ng} / \mathrm{ml}$ な゙すべて正常範囲であ った。

病理検査にて左卵巣腫瘍の一部より「境界悪性 粘液腺腫」が同定された（図 4)。

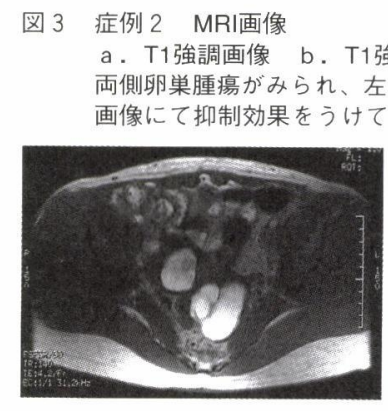

a

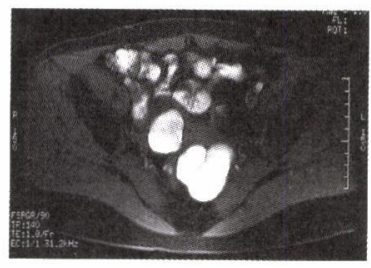

b
図4 症例 2 病理標本 $(\times 100)$

HE染色標本を示す。左卵巣腫瘍の一部よりmucinous cystic tumor of borderline malignancy が同定された。

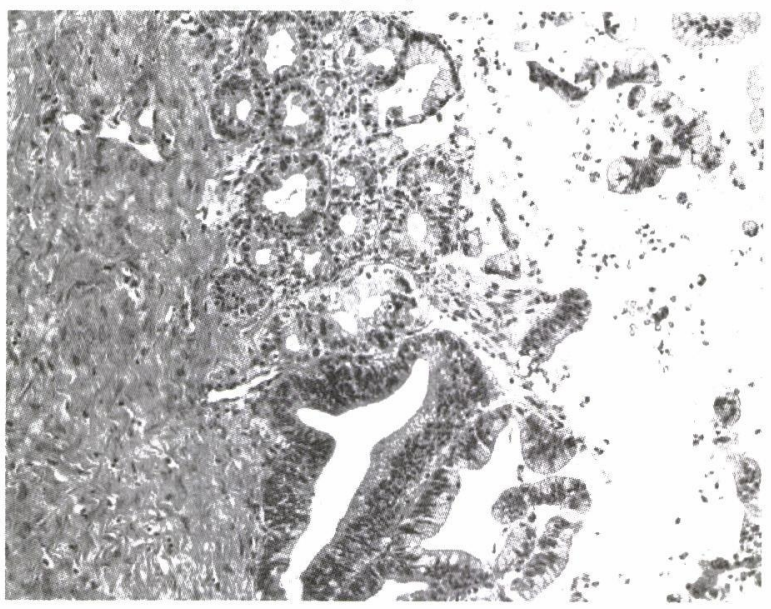

再入院し開腹手術により左付属器切除術、右卵 巣囊腫切除術を施行した。摘出標本に残存腫瘍は 認めなかった。術後約 2 年経過するが、再発兆候 を認めず現在外来フォロー中である。
症例 3

33 歳 0 回経妊 0 回経产

主訴：不妊

家族歴：特記すべきことなし

既往歴：19歳両側子宮内膜症性囊胞のため開腹に て両側卵巣震胞切除術を施行。

現病歴：子宮内膜症に対してGnRHa療法、ダナゾ ール療法などを施行。今回不妊を主訴に当科初診 した。その後不妊治療を行っていたが、初診時に は直径 $2.7 \mathrm{~cm}$ 大であった左卵巣腫瘍が 7 か月の間 に $5.8 \mathrm{~cm}$ 大にまで増大したため、手術目的にて入 院となった（図 5 )。気腹式による体内法にて腹 腔鏡下手術を行ったが、腫瘍の一部に $1-2 \mathrm{~cm}$ 大 の充実性部分があり、肉眼上は悪性腫瘍を強く疑 ったため、迅速病理診断を施行した。結果は悪性 であり開腹にて左付属器切除術を行った。術前腫 瘍マーカーはCA125：30.2 U/ml、CA19-9：11.5 $\mathrm{U} / \mathrm{ml} 、 \mathrm{CEA}$ : $1.2 \mathrm{ng} / \mathrm{ml}$ SCC : $0.9 \mathrm{ng} / \mathrm{ml}$ よ゙す ベて正常範囲であった。

永久標本による最終病理結果は「明細胞腺癌」 であった（四６）。再開腹し、腹式単純子宮全摘 術、在付属器切除術、大網切除術、骨盤リンパ節 郭清術施行し、その後TJ療法を 6 回行った。術後

図 5 症例3 MRI T2強調画像

a . 矢状断面 b. 横断面

子宮の右後方に直径 $6 \mathrm{~cm}$ 大の卵巣腫瘍が子宮に接するようにみ られる。
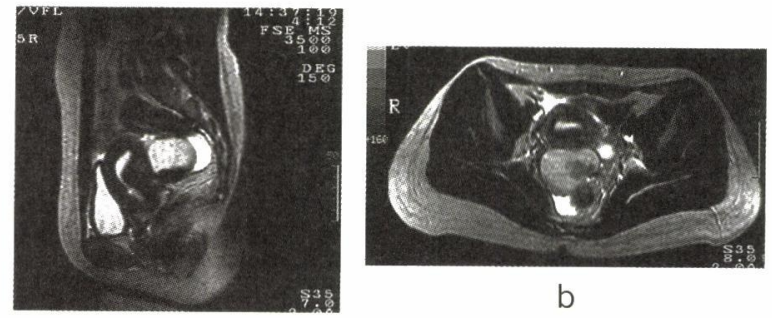

図 6 症例 3 病理標本 $(\times 100)$ HE染色標本を示す。Clear cell carcinomaの所見をみとめた。

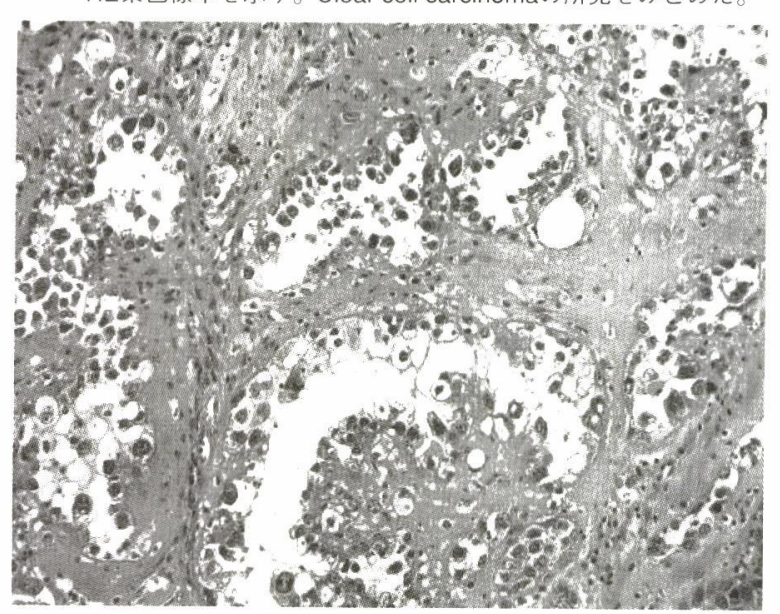


約 6 年経過するが、再発兆候を認めず現在外来フ オロー中である。

\section{考 察}

良性卵巣囊腫に対する腹腔鏡下手術は、手術侵 襲が少なく、入院期間の短縮、早期社会復帰など が可能であり、開腹術より多くの利点があるため、 近年急速に普及してきている ${ }^{1)}$ 。しかし十分な術 前評価を行っても、悪性、境界悪性卵巣腫瘍症例 に遭遇することはしばしばあり、その対応には注 意が必要である ${ }^{2)}$ 。一方、術中被膜破綻のリスク、 port site metastasisの発生などが問題点となり、 一部の施設を除いて、悪性卵巣腫瘍に対する腹腔 鏡下手術は行われていないのが現状であり、良 性・悪性の術前診断をいかに正確に行うかという ことが重要となってくる。

卵巣腫瘍の良性・悪性を術前に判断する場合に は、一般的に臨床症状、内診、腫瘍マーカーおよ び画像診断（超音波断層法、CT、MRIなど）が行 われている。中でも画像診断は特に有用であり、 卵巣癌や境界悪性腫瘍では、腫瘍内に不正な隔壁 や充実部分を認める場合が多いといわれている。 また一般に腫瘍マーカーに関しては、CA125、 CA19-9、CEA、AFP、SCCなど数種類のものを 組み合わせて用いるが、上皮性卵巣癌においては 特にCA125が重要である。しかし、CA125は年齢、 月経周期などの影響を受け、I 期癌、II 期癌での 陽性率は約 $50 \%$ であり、境界悪性腫瘍、粘液性腺 癌、明細胞腺癌などではさらに低いといわれてい $ろ^{3)}$ 。また良性腫瘍である子宮内膜症性襄胞、皮 様襄胞腫などにおいても腫瘍マーカーが上昇する ことが多く、腫瘍マーカー高值例においても、画 像診断などで悪性卵巣腫瘍が疑われない場合は、 腹腔鏡下手術を選択することが多い4)

成熟奇形種は、若年女性においては最も頻度の 高い腫瘍の一つであり、超音波、CT、MRIなどの 画像診断にて診断することがほとんどである。症 例 1 では、摘出した囊腫内に小さな未熟成分を病 理検查にて見いだしたのみであり、また術前に $\mathrm{SCCが} 1.6 \mathrm{ng} / \mathrm{ml}$ と軽度上昇していたが、それ以外 の腫瘍マーカーはすべて正常範囲であり、このよ うな症例の術前診断は非常に困難であると思われ た。また、一般に成熟奇形種の悪性転化は $2 \%$ 程 度に認められているが、その大部分は扁平上皮成 分の悪性化であるため、この場合はSCC值が高値 を示すことがあるといわれている。Moriらは、術 前に成熟奇形腫症例とその悪性転化症例を鑑別す
るには、年齢およびSCC值が最も大切であり、年 齢が39歳以下でSCC值が $2.5 \mathrm{ng} / \mathrm{ml}$ 以下の症例にお いては有意に $(\mathrm{P}<0.0001)$ 悪性転化症例が少ない と述べている ${ }^{5)}$ 。今回の症例は、年齢27歳、SCC 值は $1.6 \mathrm{ng} / \mathrm{ml}$ であり、術前に悪性を示唆する所見 がなかったため、非侵襲的な腹腔鏡下手術を選択 した。奇形腫は、未熟性に関してThurlbeckと Scullyによって提唱されNorrisにより修正された grading systemによりgrade分類され、再発の危 険性はこのgradeと相関するといわれている ${ }^{6)}$ 。 Norrisらの検討では、再発率はgrade 1で18\%、 grade $2 て ゙ 37 \%$, grade $3 て ゙ 70 \%$ と報告されている7)。 症例 1 においては術後進行期I期、grade 1であり、 27歳、未婚であることも考虑し、妊孕性温存をす るため左付属器摘出術、右卵巣部分切除術、腹腔 内観察を行った。また術後追加化学療法は行わな かったが、術後約 2 年経過した現在、再発兆候は みとめていない。

粘液性囊胞腺腫は、他の良性卵巣囊腫である子 宮内膜症性囊胞、皮様囊胞腫、漿液性囊胞腺腫な どに比べて術前の正確な診断率が低いとの報告が ある。その理由としては、内膜症性囊胞や皮様囊 胞腫は特徵的な超音波像を呈し、MRI・CTでの検 出感度が比較的良好であるが、粘液性囊胞腺腫は 特徵的（多房性で内部エコーが弱い小粒状）な像 を示さない症例が多いこと、画像および手術時の 肉眼所見では漿液性の内容液でも病理学的には粘 液を産生する上皮が認められることがあるという ことをあげている ${ }^{8)}$ 。またDaraiらは、腹腔鏡下手 術を行い判明した境界悪性腫瘍25例（槳液性12例、 粘液性13例）について検討し、50\%が多房性で、 CA125とCA19-9はそれぞれ30.7\%、23\%で上昇し ていたと報告している9)。症例2においては、術前 診断は両側子宮内膜症性囊胞であったが、術後病 理診断にて子宮内膜症性囊胞の一部に境界悪性粘 液腺腫が同定されており、その存在を術前の画像 診断でとらえるのは困難であった。また術後に振 り返ると、腫瘍は多房性であり、CA19-9が164.0 $\mathrm{U} / \mathrm{ml}$ と上昇していたため、境界悪性腫瘍も念頭に 置くべき症例であったかもしれないが、32歳、未 経産婦であり、既往に子宮内膜症性囊胞に対する 開腹手術歴があるため今回は腹腔鏡下手術を選択 した。今後同様の症例があった場合は、今回の経 験を踏まえ、十分なインフォームドコンセントの もと、治療方針を決定する必要があると思われた。 また今回の症例のように、腹腔鏡下震腫摘出術を 行い、術後病理診断が境界覀性腫瘍であった場合 
の取り扱いに関しては未だ明らかな対応は確立さ れていないのが現状である。Seracchioliらは、19 例の境界悪性腫瘍に対し腹腔鏡下手術のみを行い、 平均 42 かの観察期間で再発症例がなかったこと を報告しているが ${ }^{10)} 、 2004$ 年の卵巣がん治療ガイ ドライン 11) では、境界悪性腫瘍の治療方針は卵巣 癌に準じるとされ。基本術式およびstaging laparotomyを行うことが推奨されている。つまり 初回手術でstagingが不十分であった場合は、再開 腹によるstaging laparotomyを行うことが望まし いとされており、本症例においては、初回手術に おいて腹腔内の評価が不十分であったため（十分 なstaging laparotomyが行われていなかったため)、 再開腹の上、左付属器摘出術、腹腔内観察を行っ た。術前は両側卵巣腫瘍であったが、左卵巣腫瘍 の一部からのみ境界悪性病変がみられており、32 歳、未経産婦であるため、右卵巣は温存した。術 後化学療法は行わず経過観察しているが、術後約 2 年経過した現在、特に再発兆候はみとめていな い。

不妊治療を行っている症例の場合には、子宮内 膜症性囊胞摘出術後の卵胞発育が不良であるなど の理由により、手術をせず不妊治療を行うことが ある。症例 3 においても主訴が不妊であり、19歳 時に両側子宮内膜症性囊胞に対して開腹手術を行 った既往があることからできるだけ手術を行わず に経過を見ていたが、腫瘍が急激な増大傾向を示 したため手術となった。子宮内膜症の手術では腹 腔内を十分に観察することが重要であり、たとえ 開腹しても囊胞周囲の癒着を剥離する際に襄胞の 破裂を来すことがほとんどであり、特に不妊を主 訴とした場合はまず腹腔鏡による手術を選択し、 術中に悪性所見が疑われた場合には術中迅速病理 診断を行うべきであると思われる。子宮内膜症性 囊胞に対する小林の前方視的研究（平均観察期間 9 年間）によると、卵巣子宮内膜症患者の $0.72 \%$ (46/6,398) に卵巣癌が発生したのに対して、コン トロール群では $0.012 \% （ 7 / 57,165 ） に$ 発生してお り、卵巣子宮内膜症の相対危険率は 12.4 としてい る ${ }^{12)}$ 。さらに子宮内膜症患者より発生した卵巣癌 46 例のうち、明細胞腺癌は $39 \%$ (18/46)、類内膜 腺癌は $35 \%(16 / 46)$ であり、漿液性腺癌 $11 \%$ (5/46)、粘液性腺癌 $9 \%(4 / 46)$ と比べてその発 生頻度が高いことを報告している。また子宮内膜 症性囊胞と卵巣癌合併率の関係をみると、囊胞の 直径が $10 \mathrm{~cm}$ 超えるものや、40歳以上の症例にお いては卵巣癌の合併率が急激に増加することが知
られており、積極的に付属器摘出を考慮するべき であると思われる ${ }^{13)}$ 。今回の症例は33歳、囊胞直 径は $10 \mathrm{~cm}$ 以下であり、主訴が不妊、開腹手術の既 往があることより、開腹ではなく腹腔鏡下での囊 腫摘出術を選択した。しかし、結果的には術中迅 速病理診断にて悪性との結果が得られており、術 前診断に苦慮する症例であると思われた。術後約 6 年経過するが、再発兆候を認めず現在外来フォ ロー中である。

\section{結 語}

今回、良性卵巣囊腫の診断にて腹腔鏡下手術を 行い悪性腫瘍と判明した症例を 3 例経験した（表 1 )。いずれも若年、未経産婦の女性であり、イ ンフォームドコンセントのうえ腹腔鏡下手術を選 択したが、今後はそれぞれの腫瘍の特性、最新の 知見をふまえ、最適の手術方法を検討する必要が あると思われた。

\begin{tabular}{|c|c|c|c|c|c|c|}
\hline 症例 & 年齢 & $\begin{array}{l}\text { 経産 } \\
\text { 回数 }\end{array}$ & $\begin{array}{l}\text { 高値を示した } \\
\text { 㯵場マーカー }\end{array}$ & 術前診断 & 病理結果 & 後療法 \\
\hline 1 & 27 & 0 & $\begin{array}{l}\text { SCC: } 1.6 \\
\mathrm{ng} / \mathrm{ml}\end{array}$ & 皮様謈腫 & $\begin{array}{l}\text { Immature teratoma, } \\
\text { G1 }\end{array}$ & なし \\
\hline 2 & 32 & 0 & $\begin{array}{l}\text { CA19-9: } \\
164.0 \mathrm{U} / \mathrm{ml}\end{array}$ & $\begin{array}{l}\text { 子宮内膜 } \\
\text { 症性囊胞 }\end{array}$ & $\begin{array}{l}\text { Borderline malignancy, } \\
\text { mucinous }\end{array}$ & なし \\
\hline 3 & 33 & 0 & 全て正常篹囲 & $\begin{array}{l}\text { 子宮内膜 } \\
\text { 症性裳胞 }\end{array}$ & Clear cell carcinoma & $\mathrm{TJ} * 6$ 回 \\
\hline
\end{tabular}

${ }^{*}$ TJ (PTX: 175mg/m², CBDCA: AUC 5)

なお、本論文の要旨は第 45 回日本産科婦人科内 視鏡学会にて発表した。

\section{文 献}

1 ) Canis M, et al.: Laparoscopic management of adnexal masses suspicious at ultrasound. Obstet Gynecol 89: 679-683, 1997.

2 ) Canis M, et al.: Laparoscopic diagnosis of adnexal cystic masses: a 12-year experience with long-term follow-up. Obstet Gynecol 83: 707-712, 1994.

3 ) Mann WJ, et al.: Preoperative serum CA-125 levels in patients with surgical stage I invasive ovarian adenocarcinoma. J Natl Cancer Inst 80: 208-209, 1988.

4 ）竹田明宏、他：当科における卵巣腫瘍に対する腹腔鏡 下手術施行症例の検討. 日産婦内視鏡学会雑誌. 14: 71-74、 1998.

5 ) Mori Y, et al.: Preoperative diagnosis of malignant transformation arising from mature cystic teratoma of the ovary. Gynecol Oncol 90: 338-41, 2003.

6 ) O'Connor DM, Norris HJ.: The influence of grade on 
the outcome of stage I ovarian immature (malignant) teratomas and the reproducibility of grading. Int J Gynecol Pathol 13: 283-289, 1994.

7 ) Norris HJ, Zirkin HJ, Benson WL.: Immature (malignant) teratoma of the ovary: a clinical and pathologic study of 58 cases. Cancer 37: 2359-2372, 1976.

8 ）山田陽子、他：卵巣腫瘍の術前診断の精度に関する検 討一特に腹腔鏡下手術の適応の妥当性に関して一。産 婦人科の実際。55: 725-728、2006.

9 ) Darai E, et al.: Management and outcome of borderline ovarian tumors incidentally discovered at or after laparoscopy. Acta Obstet Gynecol Scand 77: 451-457, 1998.

10) Seracchioli R, et al:: Fertility and tumor recurrence rate after conservative laparoscopic management of young women with early-stage borderline ovarian tumors. Fertil Steril 76: 999-1004, 2001

11）日本婦人科腫瘍学会（編）：卵巣がん治療ガイドライ ン. pp11-46、金原出版、2004.

12）小林 浩：子宮内膜症から発生する卵巣腫瘍の診断と 治療. 産婦人科の実際. 53: 879-885、2004.

13）小畑孝四郎、小池英爾、椎名昌美：婦人科癌における 子宮内膜症の合併. 日本臨床. 62: 615-622、2004. 